\title{
Accumulation and effects of cadmium on sulphate-reducing bacterial biofilms
}

\author{
Chris White and Geoffrey M. Gadd \\ Author for correspondence: Geoffrey M. Gadd. Tel: +44 1382 344266. Fax: +44 1382344275. \\ e-mail: g.m.gadd@dundee.ac.uk
}

Department of Biological Sciences, University of Dundee, Dundee DD1 $4 \mathrm{HN}$, UK

\begin{abstract}
Biofilms comprising a pure and a mixed culture of sulphate-reducing bacteria (SRB) were grown in continuous culture. When exposed to 20 or $200 \mu \mathrm{M} C d$, both cultures accumulated $\mathrm{Cd}$ but the mixed culture accumulated more and continued to accumulate $\mathrm{Cd}$ during the experiment, whereas accumulation by the pure cultures ceased after 4-6 d. Unlike the pure culture, the mixed culture also accumulated both protein and carbohydrate throughout the experiment proportionally to $\mathrm{Cd}$ which showed that accumulation required the production of biofilm material. Electron microscopy showed the presence of polysaccharide and particulates in both pure and mixed cultures, irrespective of the presence of $\mathrm{Cd}$. However, energy-dispersive X-ray analysis (EDXA) showed that accumulation of $\mathrm{Cd}$ in the form of $\mathrm{CdS}$ occurred in biofilms exposed to $\mathrm{Cd}$ while back-scattered electron imaging of sections indicated that the accumulation of $\mathrm{Cd}$ was localized in a superficial layer of the biofilm. The mechanism of uptake, therefore, appeared to be entrapment and/or precipitation of CdS at the biofilm surface. The relatively low Cd uptake by the pure culture biofilm was attributed to its less efficient growth and polysaccharide production. These results indicate that mixed SRB cultures are more effective than pure cultures for metal removal and underlines significant differences between the biology of pure and mixed cultures.
\end{abstract}

Keywords: Sulphate-reducing bacteria, biofilms, cadmium, toxic metal accumulation

\section{INTRODUCTION}

Sulphate-reducing bacteria (SRB) biofilms are ubiquitous in anaerobic environments as well as having a significant economic impact through biocorrosion of metal structures (Little et al., 1990; Hamilton, 1994; Lee et al., 1995). Biofilms are now regarded as a dominant state of growth in many habitats for bacteria, including $\mathrm{SRB}$, due to the favourable conditions provided by this growth habit (Costerton et al., 1994, 1995) which include protection against stresses such as dehydration or chemical toxicity (Anwar et al., 1992; Yu \& McFeters, 1994; Costerton et al., 1995). In addition, nutrients may be concentrated at surfaces by sorption (Costerton et al., 1995) and the close proximity of organisms with complementary metabolic capacities, e.g. for carbon substrates, may enhance consortium growth and enable

Abbreviations: $\mathrm{BEI}$, back-scattered electron imaging; EDXA, energydispersive X-ray analysis; EPS, extracellular polymeric substances; SRB, sulphate-reducing bacteria. metabolic processes to modify parameters such as $\mathrm{pH}$ in a manner that is favourable to the organisms (Wimpenny et al., 1993; Costerton et al., 1994).

There are a number of mechanisms by which metals potentially interact with SRB biofilms, although little or no direct experimental work has been carried out. Precipitation of metal sulphides is significant in freeliving SRB (White \& Gadd, 1996a, b, 1997). In addition, other significant interactions may include biosorption at cell surfaces (Gadd, 1992a, b; Gadd \& White, 1993) and other biofilm components such as extracellular polymeric substances (EPS). EPS, produced during both suspended and biofilm growth of SRB, is comprised of a mixture of polysaccharides, mucopolysaccarides and proteins with the detailed composition varying with species and growth conditions (Zinkevich et al., 1996). It has been shown to bind significant amounts of potentially toxic metals (Beech \& Cheung, 1995) and has been reported to protect SRB against toxicity during biocorrosion of copper alloys (Videla, 1994). Another potentially significant role for biofilm EPS is sorption and entrapment of fine particulates which could include 
sulphides precipitated in the bulk phase (Flemming, 1995; Vieira \& Melo, 1995).

Precipitation by biogenic sulphide is an efficient means of remediating toxic metal-polluted waters (Hammack \& Edenborn, 1992; Barnes et al., 1994; White \& Gadd, 1996a, b; 1997; White et al., 1997; Gadd, 1996) but processes currently in operation are of low intensity and require large working volumes (Gadd \& White, 1993). Further development of bioprecipitation would benefit from reduction of the reactor volume, which could be achieved by the use of biofilm reactors. The current study was therefore undertaken to examine both the mechanisms involved in Cd uptake by sulphate-reducing biofilms and the effects of exposure to dissolved $\mathrm{Cd}$ on biofilm growth. Two biofilms were investigated which comprised a pure and a mixed culture, thus providing a direct comparison between the growth of pure and mixed culture biofilms, their interactions with $\mathrm{Cd}$ and potential efficacy for bioremediation of liquid effluents.

\section{METHODS}

Organisms and culture. The mixed sulphate-reducing culture was initially selected from natural sediment samples by chemostat culture (White \& Gadd, 1996a). This culture contained fermentative organisms in addition to the sulphatereducing component when grown on sugars (White $\&$ Gadd, 1996 b) but these were not evident when lactate was used as substrate and methanogenesis was not detected on any substrate (White \& Gadd, 1996a, b). The pure culture was isolated from this culture by inoculating $20 \mathrm{ml}$ anaerobic rolltube cultures of Postgates B solid medium (Postgate, 1984) with $0.1 \mathrm{ml}$ of a $10^{3} \times$ diluted chemostat culture and incubating at $20^{\circ} \mathrm{C}$ for $96 \mathrm{~h}$. Isolated colonies, identified by their black coloration, were picked and transferred to anaerobic liquid batch culture in $10 \mathrm{ml}$ sterile SL10 medium (Widdel \& Pfennig, 1981, 1982) in screw-top tubes under $\mathrm{N}_{2}$. SL10 medium comprised a salts solution (g per $950 \mathrm{ml}: \mathrm{Na}_{2} \mathrm{SO}_{4}, 4 \cdot 0$; $\mathrm{KH}_{2} \mathrm{PO}_{4}, 0.2 ; \mathrm{NH}_{4} \mathrm{Cl}, 0.25 ; \mathrm{NaCl}, 1 \cdot 0 ; \mathrm{MgCl}_{2} .6 \mathrm{H}_{2} \mathrm{O}, 0.4$; $\left.\mathrm{KCl}, 0 \cdot 5 ; \mathrm{CaCl}_{2} .2 \mathrm{H}_{2} \mathrm{O}, 0 \cdot 15 ; \mathrm{FeSO}_{4}, 0.02\right)$ which was sterilized by autoclaving $\left(121^{\circ} \mathrm{C}, 20 \mathrm{~min}\right)$ in $950 \mathrm{ml}$ batches, cooled under $\mathrm{N}_{2}$ and made up to 1 litre by means of the following additions. The two trace element solutions were sterilized separately by autoclaving $\left(121^{\circ} \mathrm{C}, 15 \mathrm{~min}\right)$. The first comprised (mg l-1) $\mathrm{MnCl}_{2} \cdot 4 \mathrm{H}_{2} \mathrm{O}(100 \cdot 0), \mathrm{CoCl}_{2} \cdot 6 \mathrm{H}_{2} \mathrm{O}(190 \cdot 0)$, $\mathrm{ZnSO}_{4} \cdot 7 \mathrm{H}_{2} \mathrm{O}(144 \cdot 0), \mathrm{H}_{3} \mathrm{BO}_{3}(6 \cdot 0), \mathrm{NiCl}_{2} \cdot 6 \mathrm{H}_{2} \mathrm{O}(24 \cdot 0)$, $\mathrm{CuCl}_{2} \cdot 2 \mathrm{H}_{2} \mathrm{O}(2 \cdot 0)$ and $\mathrm{Na}_{2} \mathrm{MoO}_{4} \cdot 2 \mathrm{H}_{2} \mathrm{O}(3 \cdot 0)$. The second comprised (mg l-1) $\mathrm{Na}_{2} \mathrm{SeO}_{3} .5 \mathrm{H}_{2} \mathrm{O}(6 \cdot 0)$ and $\mathrm{Na}_{2} \mathrm{WO}_{4} .2 \mathrm{H}_{2} \mathrm{O}$ $(8 \cdot 0)$. The vitamin solution comprised $\left(\mathrm{mg} \mathrm{l}^{-1}\right) 4$-aminobenzoic acid (4), D(+)-biotin (1.0), nicotinic acid (10.0), Ca-D $(+)$ pantothenate $(5 \cdot 0)$, pyridoxine $/ \mathrm{HCl}(15 \cdot 0)$ and thiamin $/ \mathrm{HCl}$ $(10.0)$ and was sterilized by filtration through a sterile $0.45 \mu \mathrm{m}$ pore size cellulose nitrate membrane filter (Millipore). One millilitre of each trace element and vitamin solution was added aseptically under $\mathrm{N}_{2}$ to the salts after cooling. Thirty millilitres $\mathrm{NaHCO}_{3}\left(84.0 \mathrm{~g} \mathrm{l}^{-1}\right)$ and $15.0 \mathrm{ml} \mathrm{Na} \mathrm{S}_{2} .9 \mathrm{H}_{2} \mathrm{O}(50 \mathrm{~g}$ $\left.\mathrm{I}^{-1}\right)$, pre-sterilized by autoclaving in sealed tubes $\left(121^{\circ} \mathrm{C}, 15\right.$ min) were also added and the medium $\mathrm{pH}$ was adjusted to 6.5 by addition of sterile $5 \mathrm{M} \mathrm{HCl}$. Liquid cultures were incubated for $72 \mathrm{~h}$ and used to inoculate further roll-tube cultures repeating the above process until a pure culture was obtained.

Both pure and mixed cultures were selected for attached growth using the following procedure. Thin glass coupons were made by cutting $25 \mathrm{~mm}$ square microscopic coverslips

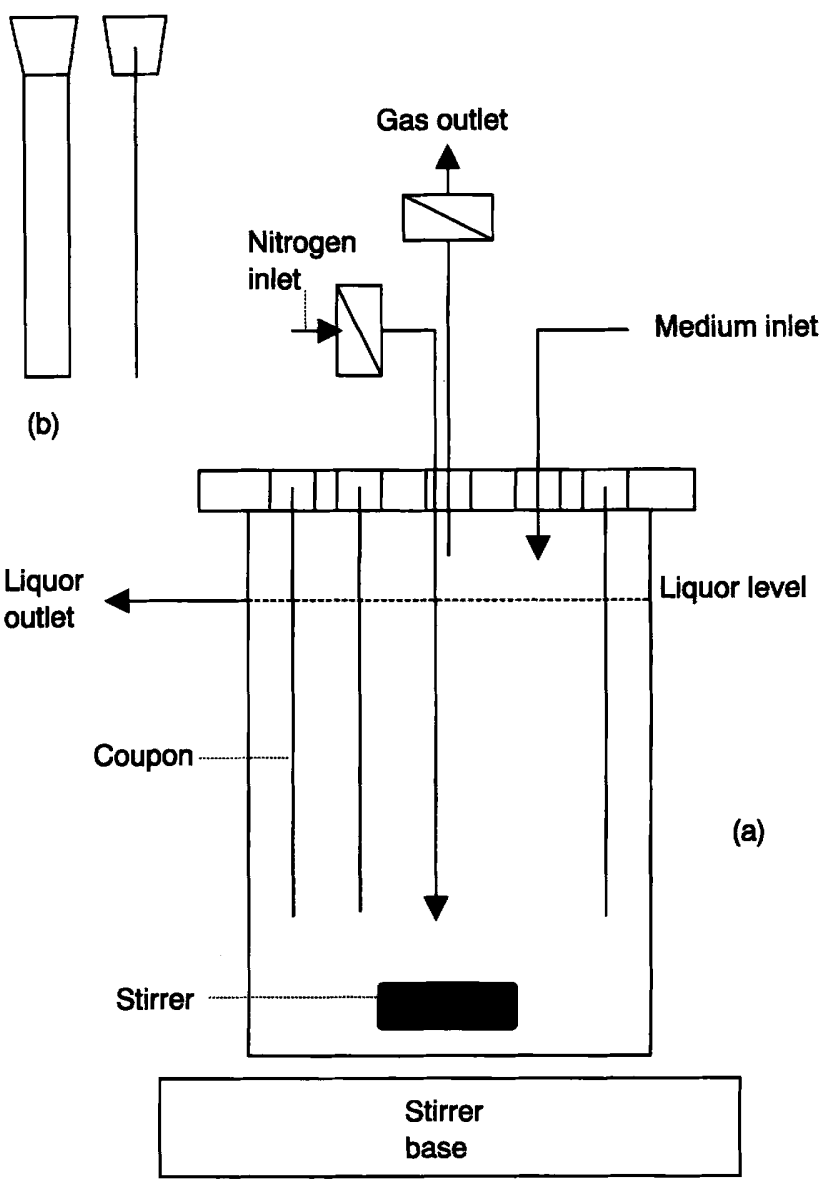

Fig. 1. Diagram to show (a) the apparatus used for continuous coupon culture of SRB biofilms. The Plastikard coupons were supported by insertion into silicone rubber bungs shown in (b). These were inserted into the polypropylene top-plate as shown in (a). The direction of gas and liquid flow is indicated by arrows.

into four parallel pieces, each of which was placed in a $12 \mathrm{ml}$ screw-top tube which was sealed and sterilized by autoclaving $\left(121^{\circ} \mathrm{C}, 15 \mathrm{~min}\right)$. Sterile, $\mathrm{N}_{2}$-sparged SL10 medium $(10 \mathrm{ml})$ was added aseptically to each tube which was then inoculated with $0.5 \mathrm{ml}$ of either culture and incubated at $20^{\circ} \mathrm{C}$ until a visible biofilm developed on the coverslip (7-14 d). The biofilm growth was then preferentially subcultured by removing the glass coupon and biofilm, snapping it in two pieces and using each half to inoculate a further culture on a similar coupon, thus inoculating two new cultures from each old culture. Once established, the biofilm cultures were maintained by the same procedure, subculturing at $14 \mathrm{~d}$ intervals.

Experimental cultures. Chemostat culture experiments were carried out in 11 glass Quickfit reaction vessels (Merck) equipped with a side-arm for outflow. The medium was stirred by means of a Flatspin solid-state magnetic stirrer (Merck) with a $25 \mathrm{~mm}$ cross-head stirrer bar operating at a constant 500 r.p.m. This maintained circulation with minimal turbulence. The vessel top-plate comprised a 6-mm-thick polypropylene disc with 20 concentrically arranged $10 \mathrm{~mm}$ diameter openings (Fig. 1a). The openings were closed with 9.5-11.0 mm diameter silicone rubber bungs which could be pierced to allow access for feeds or used to support $0 \cdot 3-\mathrm{mm}$ thick $140 \times 9 \mathrm{~mm}$ polystyrene coupons which were inserted 
into 5-mm-deep slots cut into the narrow end of the bungs and held in place using polymethacrylate adhesive (Fig. 1b). SL10 salts $(900 \mathrm{ml})$ were sterilized in the vessel, cooled in a stream of $\mathrm{N}_{2}$ and trace elements and vitamins then added. The assembled coupons and bungs were sterilized separately by immersion in $50 \%\left(\mathrm{v} / \mathrm{v}_{\mathrm{aq}}\right)$ ethanol for $24 \mathrm{~h}$ and inserted into the top plate, maintaining a stream of sterile $\mathrm{N}_{2}$. Inoculum for 11 continuous cultures was developed, also in continuous culture, in a $10 \mathrm{ml}$ syringe barrel which was sealed at the plunger end with a silicone rubber stopper containing a $0.3 \times 12 \times 60 \mathrm{~mm}$ polystyrene Plastikard (Slater) coupon. The Luer fitting of the syringe acted as an inlet port and a needle inserted through the stopper acted as an outlet. The system was sterilized by recirculating $200 \mathrm{ml} 50 \%$ ethanol for $24 \mathrm{~h}$ after which the ethanol was displaced by pumping in SL10 medium, allowing 10 changes $(100 \mathrm{ml})$. A glass coupon from a 14-d-old batch culture was then added and colonization and growth was allowed to proceed without medium addition for $48 \mathrm{~h}$, after which medium flow was started $\left(2 \mathrm{ml} \mathrm{h}^{-1}\right)$ and continuous culture maintained at $20^{\circ} \mathrm{C}$ for $14-21 \mathrm{~d}$. The biomass was then resuspended by transferring two coupons to $10 \mathrm{ml}$ sterile, anaerobic SL10 medium in a $14 \mathrm{~mm}$ i.d., $12 \mathrm{ml}$ test-tube, containing $1 \mathrm{~cm}^{3} 0.5 \mathrm{~mm}$ diameter sterile glass beads and filling the head-space with $\mathrm{N}_{2}$ before sealing and vortexing ( 3 min, 200 r.p.m.). The beads were allowed to settle and the resuspended biomass was used as inoculum for the experimental culture. After $48 \mathrm{~h}$ batch-growth, continuous culture was started and the biofilm was allowed to develop for $7 \mathrm{~d}$ in SL10 medium at $20^{\circ} \mathrm{C}$ and a dilution rate of $0 \cdot 2 \mathrm{~h}^{-1}$ to produce a standardized mature biofilm prior to the start of the experimental run. Experimental runs were carried out under identical conditions except that an appropriate volume of $100 \mathrm{mM} \mathrm{CdSO}$ was added to the SL10 medium to yield the required final $\mathrm{Cd}$ concentration and $\mathrm{Na}_{2} \mathrm{~S}$ was omitted from both control and metal-containing cultures to avoid premature precipitation of the added $\mathrm{Cd} . \mathrm{CdSO}_{4}$ stocks were made up in ultrapure water with the addition of $0.01 \% \mathrm{H}_{2} \mathrm{SO}_{4}$ (Analar, Merck) and stored in acid-rinsed polypropylene bottles.

Sampling. Samples were taken by removing entire coupons. The positions of individual coupons were numbered and they were removed in a pre-determined random sequence. Approximately $5 \mathrm{~mm}$ was removed from the distal end of each coupon prior to four $10 \mathrm{~mm}$ long subsamples being removed from the remainder of the coupon for electron microscopy and chemical assays of the biofilm $\mathrm{Cd}$, protein and carbohydrate contents, respectively. This ensured that the samples were taken from areas that were submerged under a minimum of $10 \mathrm{~mm}$ of medium during growth. Duplicate samples were taken during growth in addition to quadruplicate final samples.

Analysis. Cd was assayed by atomic absorption spectrophotometry (AAS) following digestion in $6 \mathrm{M} \mathrm{HNO}_{3}$ (White $\&$ Gadd, 1995, 1996a). Protein was extracted by vortexing the coupon in 1.0 or $2.0 \mathrm{ml} 0.5 \mathrm{M} \mathrm{NaOH}$ with the addition of approximately $0.5 \mathrm{~cm}^{3}$ of $0.5 \mathrm{~mm}$ diameter glass beads followed by extraction for $30 \mathrm{~min}$ and assaying by the Bradford method (White \& Gadd, 1996a). Carbohydrate was assayed using the anthrone method (Herbert et al., 1971) after vortexing with glass beads in the same way and removing a suitable volume of suspended biofilm. Sulphide was assayed polarographically (White \& Gadd, 1996a).

Electron microscopy. Coupon samples for scanning electron microscopy and energy-dispersive $\mathrm{X}$-ray analysis (EDXA) were fixed by immersion in $40 \%$ ethanol which strengthened the biofilm by partially dehydrating the extracellular polymeric material of the biofilm. They were then cut into $5 \mathrm{~mm}$ segments suitable for further preparation, dehydrated in successive $10 \%$ increments of ethanol concentration with three changes of absolute ethanol and critical-point-dried after which specimens for photography were sputter-coated with gold and those for EDXA analysis were carbon-coated. Dehydrated specimens were prepared for back-scattered electron imaging (BEI) by resin embedding (Wierzchos \& Ascaso, 1993). The specimen was infiltrated with LR White resin for $48 \mathrm{~h}$ and cured for $24 \mathrm{~h}$ at $60^{\circ} \mathrm{C}$. A section through the specimen was then cut and the surface polished using a microtome. Microscopy, BEI and EDXA were carried out using a JEOL JSM-35 scanning electron microscope and EDXA spectra were analysed using an Apple computer
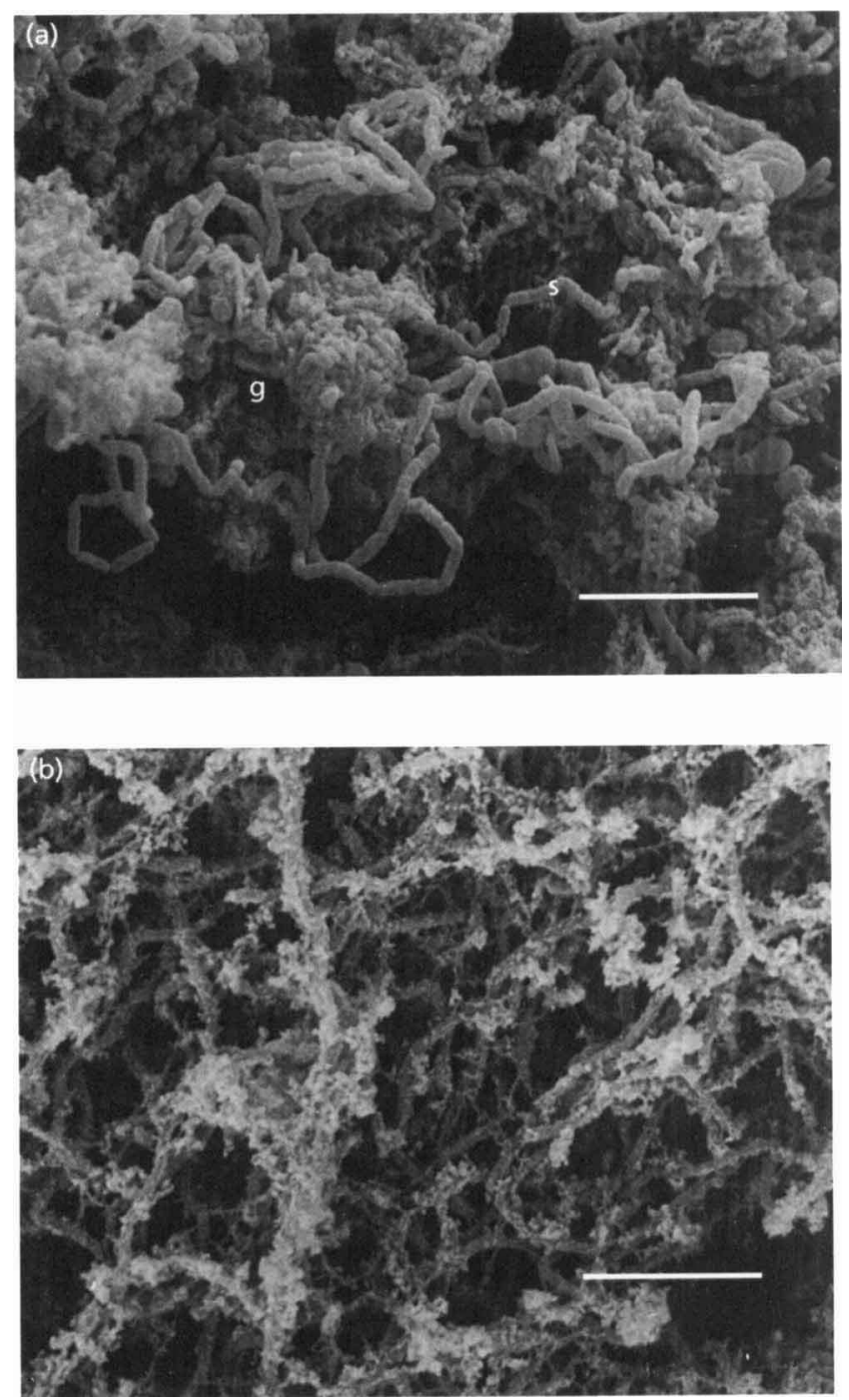

Fig. 2. Scanning electron micrographs of (a) pure and (b) mixed culture biofilms grown in unamended SL10 medium. A typical chain of cells including swollen, sporulating cells (s) is visible in (a). (b) shows a greater variety of cell-types present (although chains of cells are visible). Both micrographs show the accumulation of dehydrated extracellular polymers and granular material, although neither was grown in the presence of $\mathrm{Cd}$. An area of this material is marked ' $g$ ' in (a) while it is generally distributed in (b). Some dead material, such as fragments of cell wall, is also present in both cultures. Bars, $10 \mu \mathrm{m}$. 
equipped with a Link Interface P1445 and software (Link Systems).

\section{RESULTS AND DISCUSSION}

\section{Pure culture identification}

The pure culture was a sulphate-reducing strain which utilized lactate and ethanol but grew poorly or not at all on acetate as carbon/energy source. The organism was pleomorphic, growing in suspended culture as a slightly curved rod during early growth but also producing swollen cells and endospores in batch culture. When grown as an attached (biofilm) culture, this strain typically produced chains of cells in which those furthest from the point of attachment were medium-length rods becoming sequentially elongated, swollen and dropshaped, sporulating closer to the substratum (Fig. 2a). The chains were either attached basally producing streamers or attached throughout their length. The strain was provisionally identified on the basis of these characteristics as being a Desulfotomaculum species (Holt et al., 1994). Morphologically similar organisms formed a large proportion of cells visible in the mixed culture and appeared to perform a structural role in the biofilm (Fig. 2b).

\section{Metal uptake}

Biofilms of both pure and mixed cultures accumulated $\mathrm{Cd}$ when exposed to both 20 and $200 \mu \mathrm{M}$ Cd. Both pure and mixed cultures took up significantly more $\mathrm{Cd}$ at $200 \mu \mathrm{M}$ than at $20 \mu \mathrm{M}$ but the amount taken up by the pure culture was significantly less than that by the mixed culture at both concentrations (Table 1). This appeared to result primarily from differences between the time course of metal uptake by pure and mixed culture biofilms in that, while the initial uptake rate of $\mathrm{Cd}$ by both cultures was similar, the pure culture apparently ceased to accumulate $\mathrm{Cd}$ after $4-6 \mathrm{~d}$ at either concentration while the mixed culture continued to ac- cumulate the metal at both 20 and $200 \mu \mathrm{M}$ Cd throughout the experiment (Fig. 3).

\section{Effects of Cd on biofilm growth}

Carbohydrate content, derived primarily from the EPS component of the biofilm, can be used as an estimate of biofilm growth (Pacepavicius et al., 1997). However, possible responses by the biofilm culture to $\mathrm{Cd}$ include inhibitory effects on growth and the secretion of extracellular metal-binding proteins (Fortin et al., 1994) or (muco)polysaccharides (Beech \& Cheung, 1995) which could result in differential effects on the biofilm protein and polysaccharide production. Since protein is a more significant component of cells than EPS and the converse is true of polysaccharide, protein and polysaccharide content can together provide independent indices of cell growth and EPS development and a fuller picture of the effects of $\mathrm{Cd}$ on biofilm growth than either can provide singly. Both 20 and $200 \mu \mathrm{M} \mathrm{Cd}$ are potentially toxic to heterotrophic organisms in culture (Gadd, 1992a) and free ion concentrations of $\mathrm{Zn}$ and $\mathrm{Ni}$ in the same range have been shown to be toxic to sulphate-reducing bacteria (Poulson et al., 1997). However, there was no significant reduction in the protein content of either pure or mixed culture biofilms as a result of growth in the presence of either 20 or $200 \mu \mathrm{M}$ $\mathrm{Cd}$ (Table 1, Fig. 4a, b). This suggested that the bioavailability of $\mathrm{Cd}$ to the biofilm was reduced by factors such as precipitation as $\mathrm{CdS}$ or binding to biofilm components. The protein content of the mixed culture was approximately tenfold greater than that of the pure culture, irrespective of the Cd concentration and, while $\mathrm{Cd}$ had no effect on the protein content of the pure culture at either concentration, the presence of $200 \mu \mathrm{M}$ $\mathrm{Cd}$ in mixed cultures resulted in a small but significant increase in protein content over the control (Table 1). When the protein content of biofilms over the whole course of the experiment is considered, it is apparent that there was no overall accumulation or loss of protein

Table 1. Cd, EPS and protein accumulation by mixed and pure sulphate-reducing biofilm cultures exposed to varying Cd concentrations

Each value is the mean of eight determinations with the least significant difference (LSD) being calculated by variance analysis and comprising the residual SE of the whole data set for the three treatments multiplied by an appropriate $t$ value for the required significance level at 21 degrees of freedom (Sokal \& Rohlf, 1981). Mean values differing by more than this value can be considered as distinct at the significance level noted. Cd, protein and EPS content of pure and mixed culture biofilms subjected to 0 (control), 20 and $200 \mu \mathrm{M}$ Cd were compared using Student's $t$ test (Sokal \& Rohlf, 1981) and the cultures differed significantly in all parameters at $P<0 \cdot 01$.

\begin{tabular}{|c|c|c|c|c|c|c|}
\hline \multirow[t]{2}{*}{ Treatment } & \multicolumn{3}{|c|}{ Mixed culture } & \multicolumn{3}{|c|}{ Pure culture } \\
\hline & 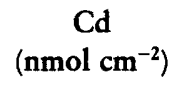 & $\begin{array}{c}\text { Protein } \\
\left(\mathbf{m g ~ c m} \mathbf{~ c m}^{-2}\right)\end{array}$ & 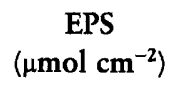 & 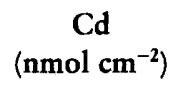 & $\begin{array}{c}\text { Protein } \\
\left\langle\mathbf{m g ~ c m}^{-2}\right)\end{array}$ & 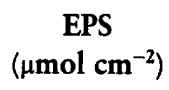 \\
\hline Control $(0 \mu \mathrm{M} \mathrm{Cd})$ & $5 \cdot 12$ & 0.99 & 0.64 & $14 \cdot 85$ & $0 \cdot 13$ & $0 \cdot 23$ \\
\hline $20 \mu \mathrm{M} \mathrm{Cd}$ & $244 \cdot 22$ & 1.03 & 0.85 & $62 \cdot 83$ & $0 \cdot 10$ & $0 \cdot 11$ \\
\hline $200 \mu \mathrm{M} \mathrm{Cd}$ & $780 \cdot 25$ & $1 \cdot 18$ & 1.76 & $222 \cdot 96$ & $0 \cdot 16$ & $0 \cdot 17$ \\
\hline $\operatorname{LSD}(P<0.01)$ & $92 \cdot 08$ & 0.08 & $0 \cdot 35$ & $26 \cdot 25$ & 0.06 & 0.06 \\
\hline
\end{tabular}




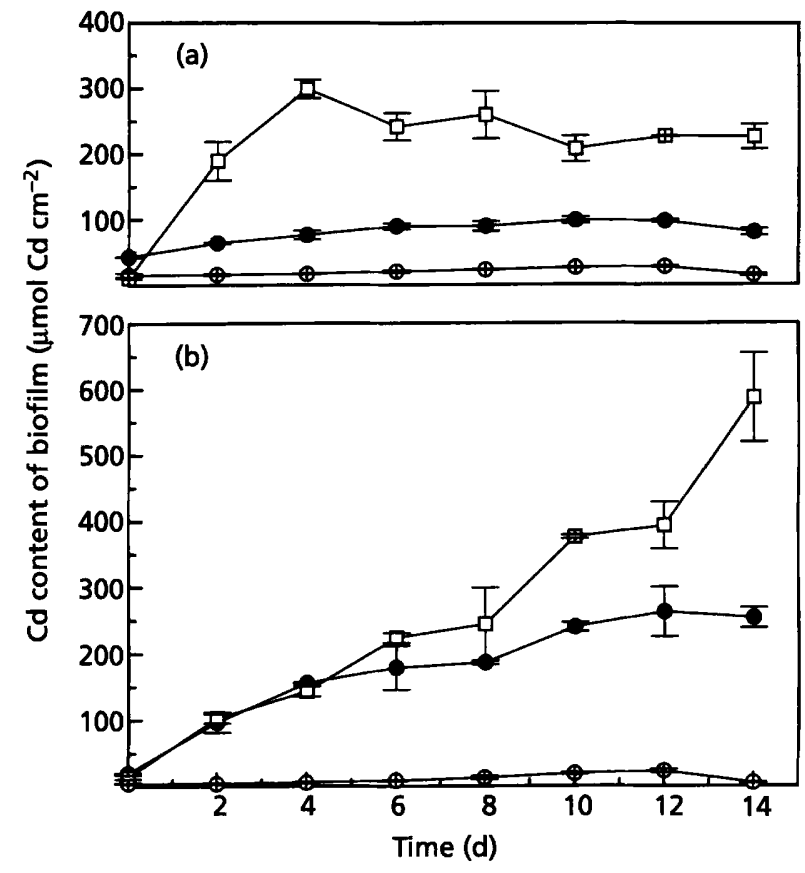

Fig. 3. Accumulation of $\mathrm{Cd}$ by (a) pure and (b) mixed culture biofilms grown in continuous culture with no added $\mathrm{Cd}$ (control) (O), $20(0)$ and $200 \mu \mathrm{M} \mathrm{Cd}(\square)$ over a period of $14 \mathrm{~d}$ growth following $7 \mathrm{~d}$ cultivation with no $\mathrm{Cd}$ present in all cases. Each point is the mean of at least two separate samples and the bars indicate the SEM.

by the pure culture (Fig. 4a), but that the mixed culture accumulated protein, the greatest accumulation occurring at $200 \mu \mathrm{M} \mathrm{Cd}$ (Fig. 4b). The polysaccharide and mucopolysaccharide components of SRB extracellular polymers are complex (Zinkevich et al., 1996) but, while not providing an absolute measurement of total EPS, the anthrone assay gives a useful index of carbohydrate content and EPS development (Kogel-Knabner, 1995). The carbohydrate content of the pure culture biofilm remained constant throughout the experiment (Fig. 5a) and there was also no significant difference between control cultures and those exposed to 20 or $200 \mu \mathrm{M} \mathrm{Cd}$ (Table 1). The control mixed culture, with no $\mathrm{Cd}$ present, contained approximately three times the amount of carbohydrate as the pure culture but also exhibited no net accumulation over time. In contrast, the mixed culture biofilms exposed to both 20 and $200 \mu \mathrm{M} \mathrm{Cd}$ both appeared to accumulate carbohydrate during the course of the experiment, with the greatest accumulation occurring at $200 \mu \mathrm{M}$ Cd (Fig. 5b). Both the protein and carbohydrate content of mixed biofilms showed a significant correlation with the Cd content of the biofilms yielding $R^{2}$ values of 0.65 and 0.60 , respectively $(P<0.01$ at 53 degrees of freedom in both cases) (Sokal \& Rohlf, 1981). This accumulation of EPS and protein could have resulted from the production of metal-binding polymers or, alternatively, it may have been due to the interaction between the biofilm and solid amorphous CdS particles precipitated in the biofilm or its immediate environment. Numerous sites in bacterial

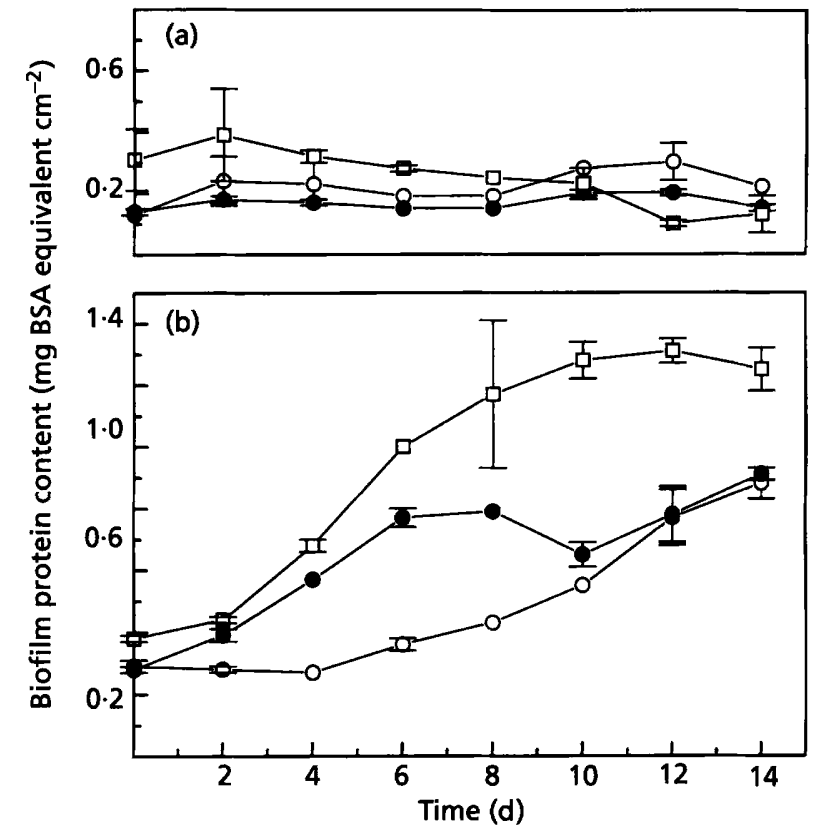

Fig. 4. Biomass growth in SRB biofilms grown in continuous culture, indicated by accumulation of protein, in (a) pure and (b) mixed culture biofilms grown with no added $\mathrm{Cd}$ (control) (O), $20(O)$ and $200 \mu \mathrm{M} \mathrm{Cd}(\square)$ over a period of $14 \mathrm{~d}$ following $7 \mathrm{~d}$ cultivation with no $\mathrm{Cd}$ present in all cases. Each point is the mean of at least two separate samples and the bars indicate the SEM.

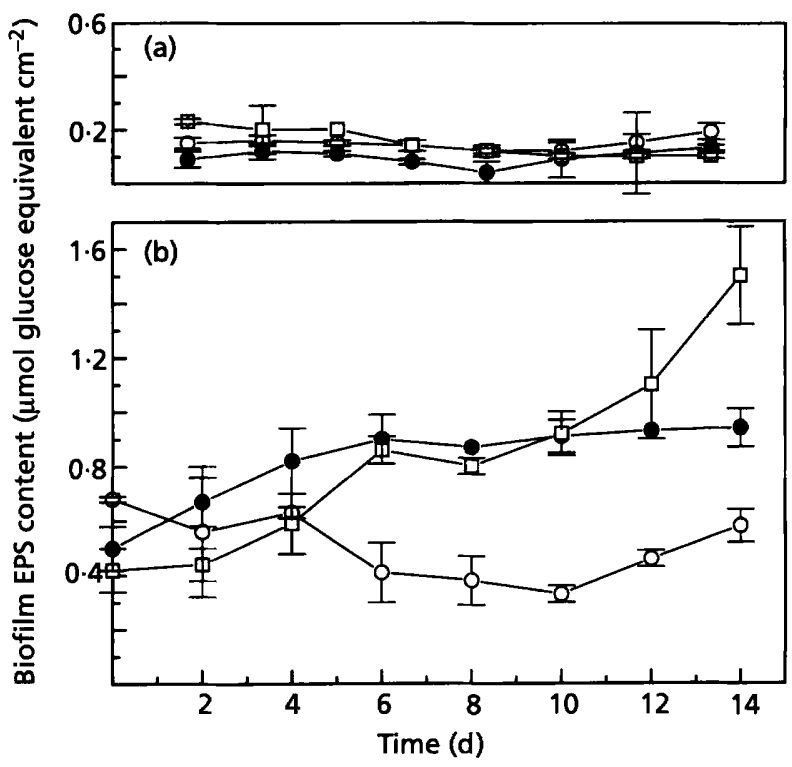

Fig. 5. Development of extracellular polymeric material by SRB biofilms in continuous culture, indicated by accumulation of polysaccharide, in (a) pure and (b) mixed culture biofilms grown with no added $\mathrm{Cd}$ (control) (O), $20(0)$ and $200 \mu \mathrm{M} \mathrm{Cd}$ $(\square)$ over a period of $14 \mathrm{~d}$ following $7 \mathrm{~d}$ cultivation with no $\mathrm{Cd}$ present in all cases. Each point is the mean of at least two separate samples and the bars indicate the SEM. 
EPS are able to interact with such particulate material (Walker et al., 1989; Flemming et al., 1990; Flemming, 1995) and clay particles are incorporated into bacterial biofilms where they produce an apparent stimulation of biofilm growth by mechanical stabilization (Vieira \& Melo, 1995).

\section{Electron microscopy}

Scanning electron micrographs of pure and mixed culture biofilms confirmed that the morphological diversity of the pure culture was less than that of the mixed culture. Because of pleomorphism, the pure culture contained a range of cell morphologies but some morphological types, such as coccoidal forms, were absent (Fig. 2a). Both in situ inspection with the naked eye and electron microscopy showed that pure culture biofilms also covered a lower proportion of the surface than mixed culture biofilms. The depth of pure culture biofilms was less than that of the mixed culture, although 2-4 mm streamers, formed from chains of cells, were only present in the pure culture. Both pure and mixed cultures contained dehydrated EPS with granular, presumably precipitated, material adhering to it and to cell surfaces. This was apparently present in similar amounts in both control cultures and those exposed to Cd [little of this material is visible in Fig. 2(a) as this micrograph was selected to illustrate the cell-types occurring in the culture]. However, EDXA analysis of the surface of the biofilm surface showed the presence of $\mathrm{Cd}$ in biofilms which had been grown in the presence of 20 or $200 \mu \mathrm{M}$ $\mathrm{Cd}$ which was absent in controls (Fig. 6). Although EDXA analysis cannot quantify uptake, the peak representing sulphur was also greatly elevated in spectra from specimens exposed to $\mathrm{Cd}$, indicating that a major component of the deposited $\mathrm{Cd}$ was CdS. This was especially striking in the spectrum obtained from the mixed culture exposed to $200 \mu \mathrm{M} \mathrm{Cd}$ where the CdS deposit was sufficiently extensive and continuous to leave only $\mathrm{Cd}$ and $\mathrm{S}$ peaks detectable and effectively mask the presence of the other elements detected in control and $20 \mu \mathrm{M}$ EDXA spectra. This confirmed that precipitation and/or binding of CdS was the major mechanism of $\mathrm{Cd}$ accumulation by the biofilms although the existence of other mechanisms of lesser importance cannot be discounted. Metallic elements, such as $\mathrm{Fe}, \mathrm{Co}$, $\mathrm{Ni}$ and $\mathrm{Zn}$, were supplied as micronutrients in the growth medium and therefore were potentially able to (a) Pure culture

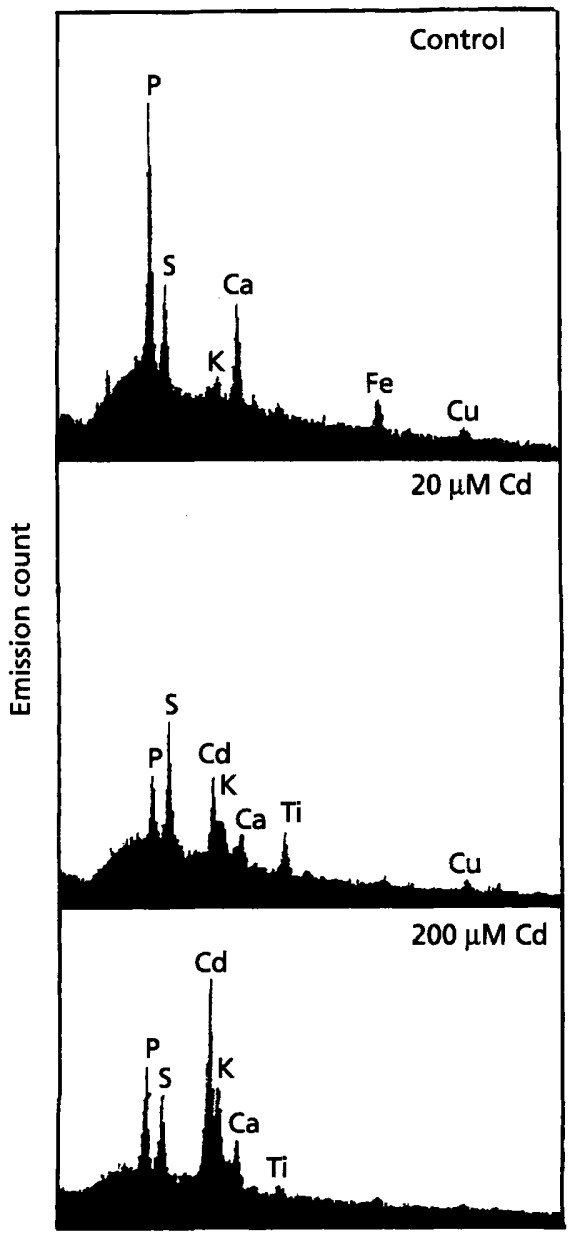

(b) Mixed culture

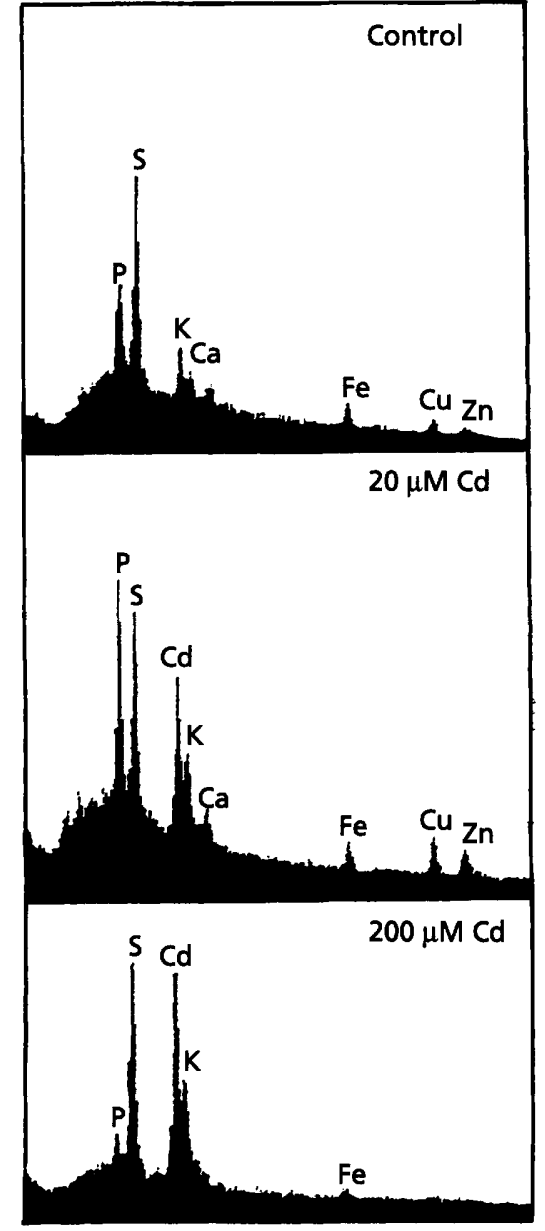

X-ray energy

Fig. 6. EDXA spectra obtained from (a) pure and (b) mixed culture biofilms following $21 \mathrm{~d}$ continuous culture. The top spectrum in each set was obtained from control cultures grown in the absence of $\mathrm{Cd}$ and the middle and lower spectra were obtained from cultures grown in 20 and $200 \mu \mathrm{M} \mathrm{Cd}$, respectively, for $14 \mathrm{~d}$ following $7 \mathrm{~d}$ development in the absence of $\mathrm{Cd}$. Clear $\mathrm{Cd}$ peaks are visible in the lower spectra which are absent in the controls and the presence of $\mathrm{Cd}$ and $\mathrm{S}$ peaks alone can be seen in the bottom right (mixed culture, $200 \mu \mathrm{M}$ Cd) spectrum. The Ti peak visible in the pure culture spectra derives from titanium white filler and was the only metallic element present in the coupon. The total emission count for each spectrum was $3.1 \times 10^{5}-3.5 \times 10^{5}$. 
compete with $\mathrm{Cd}$ for sulphide. However, except for $\mathrm{Fe}$ $(71.9 \mu \mathrm{M})$, these were largely present in concentrations less than $1 \mu \mathrm{M}$. Under the $\mathrm{pH}$ conditions occurring in the system, the solubility product constant for FeS (log $\left.K_{\mathrm{s}}=-18 \cdot 43\right)$ is higher than that of CdS $\left(\log K_{\mathrm{s}}=-28 \cdot 3\right)$ (Sillen, 1964) but would allow significant competition at the lower Cd concentration of $20 \mu \mathrm{M}$. However, the presence of a large excess $(1.0-4.5 \mathrm{mM})$ of sulphide in both pure and mixed culture systems would allow precipitation of both metals, with the relative abundance governed by their concentrations and the formation constants of their sulphides. This would therefore result in a precipitate comprising almost entirely of $\mathrm{CdS}$ when Cd was present at $200 \mu \mathrm{M}$. Quantitative chemical analysis for metals other than $\mathrm{Cd}$ was not carried out. However, peaks representing $\mathrm{Fe}$ and less significant $\mathrm{Cu}$ and $\mathrm{Zn}$ peaks were visible in EDXA spectra of both pure and mixed biofilms from control and $20 \mu \mathrm{M} \mathrm{Cd}$ cultures and it can be assumed that this represented deposition of FeS. There was no distinct peak for Fe in either biofilm at $200 \mu \mathrm{M} \mathrm{Cd}$. It is not feasible to quantify metals from EDXA spectra as they are affected by a number of factors, e.g. penetration of the target, which would be strongly affected by the presence of precipitates, but the spectra are consistent with the metal sulphide chemistry outlined above. However, the experimental system employed was not well suited to obtaining quantitative mass-balance and kinetic data and this is the subject of further experimental work in progress. BEI also showed an accumulation of electron-dense material in the biofilm exposed to $200 \mu \mathrm{M}$ Cd which was not present in the control (Fig. 7a, b). This was accumulated in a superficial layer of the biofilm and the thickness of the control biofilm was similar to the lower layer of the exposed biofilm, which contained no $\mathrm{Cd}$. Although the biofilms were dehydrated, and therefore shrunken to an unknown degree, this distribution suggested that the accumulation of $\mathrm{Cd}$ occurred in the biofilm surface, whether by precipitation or entrapment of particles, and co-accumulation of $\mathrm{Cd}(\mathrm{S})$ and biofilm material led to the greater thickness of the biofilm.

\section{Conclusions}

Both pure and mixed culture biofilms accumulated $\mathrm{Cd}$ by mechanisms which appeared to be primarily the result of entrapment or nucleation of insoluble sulphides. In comparing the interactions of the pure and mixed cultures with $\mathrm{Cd}$, a number of differences between the responses of the two cultures emerged. The growth of neither culture was inhibited by $\mathrm{Cd}$ but, even in the absence of $\mathrm{Cd}$, the pure culture showed significantly less growth than the mixed culture, containing approximately $13 \%$ of the protein and $36 \%$ of the EPS content of the mixed culture. The pure culture used was a preferentially lactate-utilizing organism while the mixed culture contained both lactate- and acetate-utilizing organisms which would allow a higher energy yield from the substrate. The possibility also exists that other complementary metabolic capacities occurred within
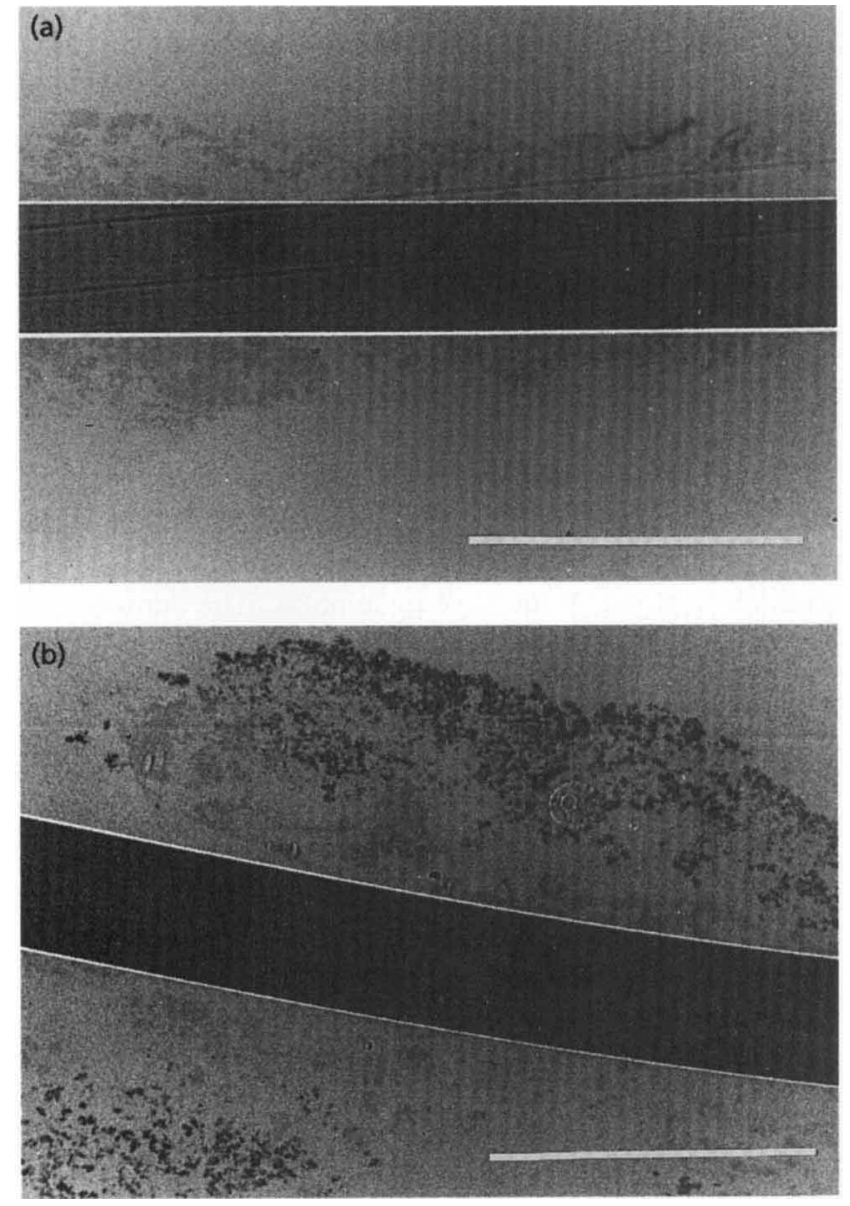

Fig. 7. Back-scattered electron images obtained from polished sections of mixed culture SRB biofilms embedded in LR White resin following growth in continuous culture for (a) $21 \mathrm{~d}$ with no $\mathrm{Cd}$ added and (b) $7 \mathrm{~d}$ with no $\mathrm{Cd}$ followed by $14 \mathrm{~d}$ with $200 \mu \mathrm{M} \mathrm{Cd}$. The layer of dark, electron-dense granules in (b) indicates the position of precipitated CdS in the biofilm. The dark band is the 'Plastikard' coupon which contained titanium white filler.

the mixed culture. Similarly, the pure culture biofilm accumulated only $25-30 \%$ of the amount of Cd accumulated by the mixed culture. Since accumulation of $\mathrm{Cd}$ within the mixed biofilm was accompanied by proportional accumulation of both protein and EPS, which did not occur in the pure culture biofilm, we can suggest that $\mathrm{Cd}$ accumulation by the pure culture was limited by its lower capacity to produce Cd-binding extracellular components. Although it is generally believed that mixed cultures have several advantages over pure cultures for environmental biotechnology, there have been few studies in which a direct comparison has been made. This study shows that the mixed culture biofilm differed from the pure culture considerably in its growth responses to $\mathrm{Cd}$, although this was composed of a major component species purified from the same mixed culture, and confirms that pure culture studies may be a poor guide to the behaviour of more complex mixed culture systems. However, while the long-term per- 
formance of the mixed culture was better than that of the pure culture, both were essentially similar in their direct interactions with $\mathrm{Cd}$ and biofilms of both cultures were capable of precipitating and immobilizing considerable quantities of $\mathrm{Cd}$ as entrapped $\mathrm{CdS}$, demonstrating the potential of sulphate-reducing biofilms for bioremediation.

\section{ACKNOWLEDGEMENTS}

G.M. Gadd gratefully acknowledges financial support from the BBSRC (LINK Programme: Biological treatment of soil and water, Ref: 94/BSW 05375). This work was carried out as part of the overall project 'Metal-biofilm interactions in sulphate-reducing bacterial systems' in collaboration with British Nuclear Fuels plc, Preston, Lancashire and Westlakes Research Institute, Whitehaven, Cumbria. The authors also wish to thank Mr Martin Kierans of this Department for assistance with electron microscopy, EDXA and BEI.

\section{REFERENCES}

Anwar, H., Strap, J. L. \& Costerton, J. W. (1992). Establishment of ageing biofilms: possible mechanism of bacterial resistance to antimicrobial therapy. Antimicrob Agents Chemother 36, 13471351.

Barnes, L. J., Scheeren, P. J. M. \& Buisman, C. J. N. (1994). Microbial removal of heavy metals and sulphate from contaminated groundwaters. In Emerging Technology for Bioremediation of Metals, pp. 38-49. Edited by J. L. Means \& R. E. Hinchee. Boca Raton, FL: Lewis Publishers.

Beech, I. B. \& Cheung, C. W. S. (1995). Interactions of exopolymers produced by sulphate-reducing bacteria with metal ions. Int Biodeterior Biodegrad 35, 59-72.

Costerton, J. W., Lewandowski, Z., DeBeer, D., Caldwell, D., Korber, D. \& James, G. (1994). Biofilms, the customized microniche. $J$ Bacteriol 176, 2137-2142.

Costerton, J. W., Lewandowski, Z., Caldwell, D. E., Korber, D. R. \& Lappin-Scott, H. (1995). Microbial biofilms. Annu Rev Microbiol 49, 711-745.

Flemming, C. A., Ferris, F. G., Beveridge, T. J. \& Bailey, G. W, (1990). Remobilization of toxic heavy metals adsorbed to bacterial wall-clay composites. Appl Environ Microbiol 56, 3191-3203.

Flemming, H.-K. (1995). Sorption sites in biofilms. Water Sci Technol 32, 27-33.

Fortin, D., Southam, G. \& Beveridge, T. J. (1994). Nickel sulfide, iron-nickel sulfide and iron sulfide precipitation by a newly isolated Desulfotomaculum species and its relation to nickel resistance. FEMS Microbiol Ecol 14, 121-132.

Gadd, G. M. (1992a). Heavy metal pollutants : environmental and biotechnological aspects. In Encyclopedia of Microbiology, pp. 351-360. Edited by J. Lederberg. San Diego: Academic Press.

Gadd, G. M. (1992b). Microbial control of heavy metal pollution. In Microbial Control of Pollution, pp. 59-88. Edited by J. C. Fry, G. M. Gadd, R. A. Herbert, C. W. Jones \& I. A. Watson-Craik. Cambridge: Cambridge University Press.

Gadd, G. M. (1996). Influence of microorganisms on the environmental fate of radionuclides. Endeavour 20, 150-156.

Gadd, G. M. \& White, C. (1993). Microbial treatment of metal pollution - a working biotechnology? Trends Biotechnol 11, 353-359.
Hammack, R. W. \& Edenborn, H. M. (1992). The removal of nickel from mine waters using bacterial sulphate-reduction. Appl Microbiol Biotechnol 37, 674-678.

Hamilton, W. A. (1994). Industrial problems due to biofilms. In Bacterial Biofilms and their Control in Medicine and Industry, pp. 109-113 Edited by J. Wimpenny, W. Nichols, D. Stickler \& H. Lappin-Scott. Cardiff: Bioline.

Herbert, D., Phipps, F. J. \& Strange, R. E. (1971). Chemical analysis of microbial cells. Methods Microbiol 5, 210-344.

Holt, G. H., Krieg, N. R., Sneath, P. H. A., Staley, J. T. \& Williams, S. T. (1994). Group 7. Dissimilatory sulfate- or sulfur-reducing bacteria. In Bergey's Manual of Determinative Bacteriology, 9th edition, pp. 335-346. Baltimore: Williams \& Wilkins.

Kogel-Knabner, I. (1995). Composition of soil organic matter. In Methods in Applied Soil Microbiology and Biochemistry, pp. 66-80. Edited by A. Kassem \& P. Namipieri. London: Academic Press.

Lee, W., Lewandowski, Z., Nielsen, P. H. \& Hamilton, W. A. (1995). Role of sulfate-reducing bacteria in corrosion of mild steel - a review. Biofouling 8, 165-187.

Little, B. J., Wagner, P. A., Characklis, W. G. \& Lee, W. (1990). Microbial corrosion. In Biofilms, pp. 635-670. Edited by W. G. Characklis \& K. C. Marshall. New York: Wiley.

Pacepavicius, G., Lau, Y. L., Liu, D., Okamura, H. \& Aoyama, I. (1997). A rapid biochemical method for estimating microbial biomass. Environ Toxicol Water Qual 12, 97-100.

Postgate, J. R. (1984). The Sulphate-Reducing Bacteria. Cambridge: Cambridge University Press.

Poulson, S. R., Colberg, P. J. S. \& Drever, J. I. (1997). Toxicity of heavy metals $(\mathrm{Ni}, \mathrm{Zn})$ to Desulfovibrio desulfuricans. Geomicrobiol J 14, 41-49.

Sillen, L. G. (1964). Inorganic ligands. In Stability Constants of Metal-Ion Complexes, pp. 1-356. Edited by L. G. Sillen \& A. E. Martell. London: The Chemical Society.

Sokal, R. R. \& Rohlf, F. J. (1981). Biometry. Oxford: W. H. Freeman.

Videla, H. A. (1994). Biocorrosion of nonferrous metal surfaces. In Biofouling and Biocorrosion in Industrial Water Systems, pp. 231-243. Edited by G. G. Geesey, Z. Lewandowski \& H. K. Flemming. Boca Raton, FL: Lewis Publishers.

Vieira, M. J. \& Melo, L. F. (1995). Effect of clay particles on the behaviour of biofilms formed by Pseudomonas fuorescens. Water Sci Technol 32, 45-52.

Walker, S. G., Flemming, C. A., Ferris, F. G., Beveridge, T. J. \& Bailey, G. W. (1989). Physicochemical interaction of Escherichia coli cell envelopes and Bacillus subtilis cell walls with two clays and ability of the composite to immobilize heavy metals from solution. Appl Environ Microbiol 55, 2976-2984.

White, C. \& Gadd, G. M. (1995). Determination of metals and metal fluxes in algae and fungi. Sci Total Environ 176, 107-115.

White, C. \& Gadd, G. M. (1996a). Mixed sulphate-reducing bacterial cultures for bioprecipitation of toxic metals: factorial and response-surface analysis of the effects of dilution rate, sulphate and substrate concentration. Microbiology 142, 2197-2205.

White, C. \& Gadd, G. M. (1996b). A comparison of carbon/energy and complex nitrogen sources for bacterial sulphate reduction: potential applications to bioprecipitation of toxic metals as sulphides. J Indust Microbiol 17, 116-123.

White, C. \& Gadd, G. M. (1997). An internal sedimentation 
bioreactor for laboratory-scale removal of toxic metals from soil leachates using biogenic sulphide precipitation. $J$ Indust Microbiol Biotechnol 18, 414-421.

White, C., Sayer, J. A. \& Gadd, G. M. (1997). Microbial solubilization and immobilization of toxic metals: key biogeochemical processes for treatment of contamination. FEMS Microbiol Rev 20, 503-516.

Widdel, F. \& Pfennig, N. (1981). Studies on dissimilatory sulfatereducing bacteria that decompose fatty acids. 1. Isolation of new sulfate-reducing bacteria enriched with acetate from saline environments - description of Desulfobacter postgatei gen. nov., sp. nov. Arch Microbiol 129, 395-400.

Widdel, F. \& Pfennig, N. (1982). Studies on dissimilatory sulfatereducing bacteria that decompose fatty acids. 2. Incomplete oxidation of propionate by Desulfobulbus propionicus gen. nov., sp. nov. Arch Microbiol 131, 360-365.

Wierzchos, J. \& Ascaso, C. (1993). Application of back-scattered electron imaging to the study of the lichen-rock interface. $J$ Microsc 175, 54-59.

Wimpenny, J. W. T., Kinniment, S. L. \& Scourfield, M. A. (1993). The physiology and biochemistry of biofilm. In Microbial Biofilms: Formation and Control, pp. 51-94. Edited by S. P. Denyer, S. P. Gorman \& M. Sussman. Oxford: Blackwell Scientific Publications.

Yu, F. P. \& McFeters, G. A. (1994). Physiological responses of bacteria in biofilms to disinfection. Appl Environ Microbiol 60, 2462-2466.

Zinkevich, V., Bogdarina, I., Kang, H., Hill, M. A. W., Tapper, R. \& Beech, I. B. (1996). Characterization of exopolymers produced by different isolates of marine sulphate-reducing bacteria. Int Biodeterior Biodegrad 37, 163-172.

Received 16 October 1997; revised 22 December 1997; accepted 19 January 1998. 